\title{
De samenhang tussen fysieke en sociale veiligheid in theorie en praktijk
}

\author{
Hanneke Duijnhoven, Kim van Buul-Besseling \& Nathalie Vink
}

\begin{abstract}
Dit artikel bespreekt de samenhang tussen de werkvelden van fysieke en sociale veiligheid. Op basis van resultaten van een onderzoeksproject over multidisciplinaire samenwerking en informatiedeling in het veiligheidsdomein in Nederland beargumenteren we dat het niet realistisch is om te spreken van twee onafhankelijke werkvelden, maar dat het zinvoller is om te spreken over één veiligheidsdomein waarbinnen situaties van onveiligheid vanuit een breder (fysiek én sociaal) perspectief worden bekeken. In het artikel bespreken we de mogelijkheden die wij zien om de werkvelden van fysieke en sociale veiligheid beter op elkaar te laten aansluiten.
\end{abstract}

\section{Inleiding}

Er is de afgelopen jaren veel onderzoek gedaan naar multidisciplinaire samenwerking binnen het veld van rampenbestrijding en crisisbeheersing (fysieke veiligheid). Dit onderzoek richt zich veelal op de samenwerking tussen professionals vanuit verschillende disciplines (brandweer, GHOR, politie) in de responsfase van crises en incidenten. Ervoor zorgen dat er tussen de verschillende professionals een gedeelde interpretatie (i.e. common operational picture) van een crisissituatie ontstaat, wordt hierbij vaak als een belangrijk aspect gezien (e.g. Wolbers \& Boersma 2013). Ook informatiedeling en het omgaan met verschillen in werkwijzen, organisatiecultuur en verschillende doelstellingen wordt genoemd als een belangrijke factor in het verbeteren van de bestrijding van incidenten (e.g. Allen, Karanasios \& Norman 2013; Mishra, Allen \& Pearman 2011; Treurniet, Logtenberg \& Groenewegen 2014). Opvallend genoeg beperkt dat onderzoek zich grotendeels tot het terrein van de fysieke veiligheid. Dit kan deels verklaard worden door de schaal en impact van fysieke rampen, waarbij er vaak sprake is van een flitsincident waarop hulpdiensten snel moeten reageren. Het goed kunnen samenwerken door uiteenlopende professionele partijen in een complexe crisissituatie is echter ook relevant en van toepassing voor het veld van de sociale veiligheid. Sterker nog, de hulpdiensten die doorgaans betrokken zijn bij incidenten in de fysieke veiligheid spelen vaak ook een rol bij situaties van onveiligheid binnen het werkveld van de sociale veiligheid. Dat betekent dat de kennis over multidisciplinaire samenwerking die is opgedaan binnen de fysieke veiligheid wellicht ook relevant is voor een toepassing binnen het bredere veiligheidsdomein. Tot op heden is hier echter weinig aandacht aan besteed, omdat zowel in de praktijk als in onderzoek de werkvelden van fysieke en sociale veiligheid doorgaans als afzonderlijke werelden worden gezien.

In dit artikel bespreken we de resultaten van een onderzoek naar de samenhang tussen de werkvelden van fysieke en sociale veiligheid. Het onderzoek maakt 
onderdeel uit van een onderzoeksprogramma dat gericht is op de multidisciplinaire samenwerking binnen het veiligheidsdomein in Nederland. ${ }^{1}$ Uitgangspunt van het onderzoek is het inzicht dat professionals binnen het domein van veiligheid allen vanuit hun eigen specialistische kennis een essentiële bijdrage leveren aan de beheersing en bestrijding van crisissituaties en incidenten, maar dat samenwerking met andere partijen bemoeilijkt kan worden door hun specifieke disciplinaire en organisatieculturele perspectieven (Allen et al. 2013). In deze bijdrage willen wij beargumenteren dat het onderscheid tussen de werkvelden van fysieke en sociale veiligheid vanuit theoretisch en organisatorisch oogpunt weliswaar logisch is, maar dat dit ervoor zorgt dat er onvoldoende aandacht is voor de multidisciplinaire aspecten van veiligheid over de grenzen van deze werkvelden heen. In het bijzonder kijken we hierbij naar de positie van de gemeente met betrekking tot de veiligheidszorg. De burgemeester is verantwoordelijk voor de veiligheid van de burgers in zijn/haar gemeente en vanuit die optiek is het niet zinvol om te spreken over een onderscheid tussen fysieke of sociale veiligheid. Immers, voor de burgers is veiligheid één thema, zij voelen zich wél of niet veilig. Dit artikel volgt de stappen die we in het onderzoek hebben genomen. Het onderzoek is gestart met een literatuurstudie met betrekking tot de definities en toepassing van de begrippen fysieke en sociale veiligheid (par. 2). Vervolgens hebben we aan de hand van een analyse van een aantal incidentevaluaties onderzocht hoe het onderscheid tussen beide werkvelden zich in de praktijk manifesteert (par. 3). De resultaten van die analyse hebben we als uitgangspunt genomen om de problematiek verder te verkennen, door middel van interviews en een aantal interactieve workshops met actoren die actief zijn in het veiligheidsdomein (par. 4). In ons onderzoek streven we naar het tot stand brengen van de juiste verbindingen tussen de verschillende partijen met lange tradities van het werken in deze velden. Om die reden hebben we interviews gehouden met professionals vanuit verschillende organisaties die actief zijn in het veiligheidsdomein (zowel binnen het werkveld sociale veiligheid als fysieke veiligheid). De respondenten waren afkomstig uit Veiligheidsregio's, politie, Veiligheidshuizen en gemeenten. Naast de interviews hebben we een workshop georganiseerd met deelnemers vanuit verschillende organisaties om op een interactieve manier te achterhalen waar de ervaren knelpunten zitten met betrekking tot samenwerking en informatiedeling rondom incidenten en onveilige situaties. Omdat in de interviews en tijdens de workshop duidelijk naar voren kwam dat met name de gemeente (in de persoon van de burgemeester, ondersteund door adviserende ambtenaren Openbare Orde en Veiligheid) een regierol heeft in de (lokale) veiligheidszorg, hebben we met een kleinere groep gemeentelijke ambtenaren in vervolggesprekken en een tweetal workshops verkend waar mogelijkheden zitten voor verbeteringen met betrekking tot de aanpak van veiligheid in brede zin. In het laatste deel van het artikel (par. 5) bespreken we aan de hand van de resultaten uit deze sessies enkele mogelijke oplossingsrichtingen die wij zien om te komen tot meer samenhang binnen het veiligheidsdomein.

1 Het hier gerapporteerde onderzoek maakt onderdeel uit van een vraaggestuurd onderzoeksprogramma 'Beter benutten van informatiestromen en samenwerking' van TNO. 


\section{Fysieke en sociale veiligheid}

Het begrip veiligheid is de laatste jaren in toenemende mate een containerbegrip geworden dat voor uiteenlopende onderwerpen en in uiteenlopende sectoren wordt gebruikt (Boutellier 2005; 2007; De Graaf 2013; Deklerck 2006; Resodihardjo \& Kors-Walraven 2012; Van Noije 2011). De steeds bredere - en daarmee steeds abstractere - toepassing van het label 'veiligheid' heeft ervoor gezorgd dat er ook een toename is in het aantal verschillende voorvoegsels dat wordt gebruikt om aan te geven wat voor type veiligheid bedoeld wordt (zoals interne of externe veiligheid, subjectieve of objectieve veiligheid, en fysieke of sociale veiligheid). Pleysier spreekt in dat kader over de opkomst van het 'veiligheidsparadigma' dat gepaard gaat met een eigen discours (2008). Waar voorheen werd gesproken over de bestrijding van rampen en de bestrijding van criminaliteit en antisociaal gedrag wordt nu gesproken over het bevorderen van (respectievelijk) de fysieke en sociale veiligheid (Resodihardjo \& Kors-Walraven 2012). Ook in de praktijk worden fysieke veiligheid en sociale veiligheid beschouwd als twee onafhankelijke velden met een eigen dynamiek en eigen partijen, rollen en taken. Fysieke veiligheid betreft het werkveld dat met name is gericht op rampenbestrijding en crisisbeheersing, terwijl sociale veiligheid het werkveld is van criminaliteit, overlast en leefbaarheid. Fysieke veiligheid is in de huidige situatie belegd bij de primaire hulpverleningsdiensten (brandweer, GHOR en politie) en de coördinerende Veiligheidsregio's, terwijl sociale veiligheid voornamelijk wordt opgepakt door gemeenten, politie, welzijnsorganisaties en coördinerende Veiligheidshuizen.

In de literatuur wordt het onderscheid tussen fysieke en sociale veiligheid op verschillende dimensies gemaakt. Sommige auteurs leggen het onderscheid in de oorzaak (schuldvraag), waarbij fysieke dreigingen worden veroorzaakt door de natuur, technologisch of menselijk falen, en sociale dreigingen het resultaat zijn van intentioneel menselijk handelen (Boers, Van Steden \& Boutellier 2008; Helsloot 2007). Dit onderscheid is echter niet volledig houdbaar wanneer de nadruk meer komt te liggen op de beheersing of aanpak van een dreiging, want op het moment dat er een grote brand woedt of wanneer er een explosie is geweest, is de bestrijding niet per se anders wanneer het gaat om een ongeluk of een aanslag: de brand wordt op eenzelfde manier geblust.

In een iets andere toepassing van het onderscheid in de oorzaak van de dreiging wordt fysieke onveiligheid veroorzaakt door dreigingen die van 'buiten' komen (vanuit andere landen, vanuit de natuur of vanuit de technologie). Dreigingen die van 'binnen' komen (veroorzaakt door burgers onderling) zijn vormen van sociale onveiligheid (i.e. Bruinsma et al. 2004). Het onderscheid wordt nog lastiger wanneer we kijken naar een terroristische aanslag. In de praktijk valt de bestrijding en beheersing van een aanslag binnen het werkveld van de fysieke veiligheid, maar strikt genomen wordt het veroorzaakt door doelbewust menselijk handelen, waardoor het zou moeten worden gezien als een sociaal veiligheidsincident. Bovendien kan een terroristische dreiging zowel van buiten als van binnen komen. 
Een andere dimensie waarop het onderscheid tussen fysiek en sociaal wordt gemaakt, heeft betrekking op de gevolgen van een dreiging. Een brand of een overstroming heeft voornamelijk fysieke gevolgen (doden, gewonden, materiële schade), terwijl de gevolgen van een rel of conflict tussen twee groepen inwoners in een wijk met name van psychosociale aard zijn (angstgevoelens, woede of maatschappelijke onrust). Met andere woorden, fysieke veiligheid gaat over het beschermen van het eigen lichaam en de directe omgeving van personen, terwijl sociale veiligheid te maken heeft met het beschermen van de positie en levensomstandigheden van personen (Bauman, in Schuilenburg 2009, 9). Ook dit onderscheid is niet volledig houdbaar, omdat een fysieke dreiging ook onrust of angst teweeg kan brengen en rellen of ruzies ook gepaard kunnen gaan met fysieke schade (i.e. Van den Brand 2005).

Veel auteurs verwijzen afwisselend naar beide dimensies, maar vaker nog wordt de definitie niet expliciet benoemd. Het lijkt erop dat het voornamelijk een pragmatisch onderscheid is, dat wordt gebruikt om de scheiding van taken en verantwoordelijkheden zoals deze zijn belegd bij verschillende partijen te duiden. Dit hoeft in principe geen probleem te zijn, de partijen die actief zijn binnen het veiligheidsdomein weten immers vanuit hun eigen discipline en de organisatorische structuur heel goed wat ze moeten doen en waar hun verantwoordelijkheid ligt. Toch willen wij beargumenteren dat de inconsistenties in het onderscheid problematisch zijn. De harde scheiding tussen de werkvelden leidt tot een zekere vorm van 'verzuiling' of 'verkokering', waardoor onvoldoende de volledige impact van gebeurtenissen in beschouwing wordt genomen, wat een belemmering vormt voor de aanpak en de oplossing van de situatie.

\section{Fysieke of sociale incidenten?}

Om een beter beeld te krijgen van het onderscheid tussen fysieke en sociale veiligheid in de praktijk hebben we een aantal grootschalige incidenten bestudeerd. Bij het bestuderen hebben we onszelf de vraag gesteld of een incident binnen het fysieke of het sociale werkveld kan worden geplaatst. We hebben onderzocht wat de belangrijkste aspecten van de betreffende incidenten zijn geweest en hoe de perspectieven van de betrokken partijen het verloop van een incident kunnen hebben beïnvloed. In totaal hebben we zeven incidenten geanalyseerd. Een randvoorwaarde voor het selecteren van een incident was de beschikbaarheid van (evaluatie)documentatie. De uiteindelijke keuze voor deze zeven incidenten is gebaseerd op een variëteit in de aard, oorzaak, omvang en locatie van het incident. Er is gekozen voor incidenten die in de periode van 2003-2013 hebben plaatsgevonden, waardoor de meest recente organisatiestructuren zijn meegenomen. Als primair brondocument is voor de casusanalyse gekozen voor evaluatierapporten. Omdat de meeste evaluaties zijn opgesteld vanuit het perspectief van de primaire hulpdiensten, gaan ze met name in op aspecten die te maken hebben met het optreden van deze partijen (zoals de procedures rondom opschaling en de communicatie vanuit de Veiligheidsregio naar de media). Andere bronnen dan de evaluatierapporten (zoals mediaberichten) zijn daarom geraadpleegd om de tot- 
Tabel 1 Overzicht van geanalyseerde incidenten

\begin{tabular}{|c|c|c|}
\hline Incident & Omschrijving & Primaire bron \\
\hline $\begin{array}{l}\text { Stroomstoring Bommeler- } \\
\text { waard }\end{array}$ & $\begin{array}{l}\text { Op } 12 \text { december } 2007 \text { werd de } \\
\text { Bommelerwaard getroffen door } \\
\text { een stroomstoring die dagenlang } \\
\text { aanhield. }\end{array}$ & Scholtens \& Helsloot 2008 \\
\hline Moskeebrand Helden & $\begin{array}{l}\text { Op } 13 \text { november } 2004 \text { wordt } \\
\text { een brand ontdekt in de moskee } \\
\text { van Helden. }\end{array}$ & Witte, Brassé \& Schra 2005 \\
\hline $\begin{array}{l}\text { Ingestorte steiger Geertrui- } \\
\text { denberg }\end{array}$ & $\begin{array}{l}\text { Op } 28 \text { september } 2003 \text { stort in } \\
\text { de Amercentrale in Geertrui- } \\
\text { denberg een } 65 \text { meter hoge stei- } \\
\text { ger in, waarbij acht mensen tus- } \\
\text { sen het ingestorte steigermateri- } \\
\text { aal terechtkomen. }\end{array}$ & $\begin{array}{l}\text { Helsloot, Jong, Zannoni, } \\
\text { Vinck Mcdm, Lukkes \& Mul. } \\
\text { ler } 2004\end{array}$ \\
\hline Gaslek Heinenoord & $\begin{array}{l}\text { Op } 12 \text { oktober } 2007 \text { werd een } \\
\text { gaslek vermoed bij de buisleidin- } \\
\text { genstraat in Heinenoord. }\end{array}$ & $\begin{array}{l}\text { Regionale Brandweer Zuid- } \\
\text { Holland Zuid } 2007\end{array}$ \\
\hline Paasvuur Espelo & $\begin{array}{l}\text { Op } 8 \text { april } 2012 \text { vond het groot- } \\
\text { ste paasvuur ter wereld plaats in } \\
\text { Espelo. Bij het Paasvuur raakte } \\
\text { een cameraman gewond door } \\
\text { een losgeschoten kabel. }\end{array}$ & $\begin{array}{l}\text { Meerenburgh, Mentink, } \\
\text { Hanstede \& Perrier } 2012\end{array}$ \\
\hline Hoogwater Groningen & $\begin{array}{l}\text { Begin januari } 2012 \text { bedreigden } \\
\text { hoogwatersituaties de Gronin- } \\
\text { ger Tolberterpettenpolder en } \\
\text { het gebied rond Woltersum. }\end{array}$ & Haasjes e.a. 2012 \\
\hline $\begin{array}{l}\text { Schietincident } \\
\text { Alphen aan den Rijn }\end{array}$ & $\begin{array}{l}\text { Op } 9 \text { april } 20 \text { I I schoot Tristan } \\
\text { van der V. zes mensen dood in } \\
\text { een winkelcentrum in Alphen } \\
\text { aan den Rijn. }\end{array}$ & IOOV 20II \\
\hline
\end{tabular}

standkoming van het overzicht vanuit een bredere focus te benaderen en nader in te vullen. In tabel 1 staat een overzicht van de geselecteerde incidenten, aangevuld met een korte omschrijving van het incident en de geraadpleegde bronnen.

Bij het toewijzen van concrete casussen aan het fysieke of sociale werkveld werd duidelijk dat de afbakening problemen met zich meebrengt. Er zijn aspecten van een incident die tegelijkertijd een sociale en een fysieke component hebben en de manier waarop ze worden ingevuld, hangt sterk af van het perspectief waarmee iemand naar een incident kijkt. Dit sluit ook aan bij de constatering dat de scheiding van de werkvelden van fysieke en sociale veiligheid vooral te maken heeft met de 'verzuiling' van het terrein van crisisbeheersing en rampenbestrijding enerzijds en criminaliteit en leefbaarheid anderzijds. Iemand die actief is binnen het werkveld van de fysieke veiligheid zal de aspecten in eerste instantie vanuit een 'fysiek perspectief' invullen, terwijl iemand vanuit het werkveld van de sociale 
veiligheid waarschijnlijk een 'sociaal perspectief' hanteert. Zo kan één en hetzelfde incident vanuit een fysiek perspectief worden beschouwd als een brand die de brandweer onder controle moet krijgen. Vanuit een sociaal perspectief kan het worden beschouwd als een man die uit huis dreigt te worden geplaatst en uit woede zijn woning in brand steekt, waarbij naast de betreffende man ook zijn familieleden, buren en eventueel andere betrokkenen opgevangen dienen te worden. Beide perspectieven kunnen afzonderlijk van elkaar zorgen voor bepaalde 'blinde vlekken', waardoor de reacties op een gebeurtenis of incident misschien niet optimaal zijn. De invullingen van beide perspectieven zijn legitiem en behoeven allebei aandacht.

Dat de organisatorische scheiding in de praktijk kan leiden tot verzuiling tussen de organisaties en het optreden, is ook terug te zien in een aantal observaties naar aanleiding van de analyse. Allereerst kan de tijdgeest een essentieel element zijn van de aanleiding, bestrijding en behandeling van een incident. Dat blijkt onder andere uit de casus van de Moskeebrand in Helden. Op het eerste oog lijkt dit incident te vallen binnen het fysieke veiligheidswerkveld. De bestrijding en opvolging van een dergelijk incident is in handen van de primaire hulpverleningsdiensten (brandweer, GHOR en politie). Wanneer we echter verder kijken naar de omstandigheden van dit voorbeeld, dan blijkt dat de typering van fysieke veiligheid niet de volledige lading dekt van de gebeurtenissen en dat de tijdgeest om extra aandacht vraagt rondom de aanpak en afhandeling van dit incident.

In 2004 heerst er in Nederland een gespannen klimaat dat terug te leiden is tot de aanslagen op het WTC gebouw in 2001 (9-11). Sindsdien is de politieke en maatschappelijke situatie verscherpt. Voorafgaand aan de moskeebrand in Helden vindt er een hele reeks aan incidenten plaats. Elf dagen voor de brand wordt Theo van Gogh vermoord in Amsterdam door een islamitische en geradicaliseerde Nederlandse jongere van Marokkaanse afkomst. De dag na de moord worden in Den Haag islamitische jongeren aangehouden op verdenking van terrorisme (Hofstadgroep). In de daaropvolgende dagen doen zich op veel plaatsen in Nederland incidenten voor die vermoedelijk in verband staan met de moord op Theo van Gogh. Moskeeën, kerken en scholen zijn doelwit van brandstichting en bekladding. Wanneer in Helden een paar uur voor de viering van het Suikerfeest een brand wordt aangestoken in een moskee, krijgt dit incident enorme mediaaandacht, omdat dit het zoveelste incident is in Nederland ten gevolge van interetnische spanningen. De gemeente krijgt te maken met grote aandacht van lokale, regionale, landelijke en zelfs internationale media. Tegelijkertijd zijn haar werkzaamheden gericht op de opvang van betrokkenen en bewoners van de gemeente, communicatie naar betrokken partners (incl. bevolking) en het voorkomen van escalatie en spanningen op langere termijn (Witte et al. 2005).

Deze achtergronden plaatsen het incident in een ander licht en hiermee verschuift de nadruk van het fysieke veiligheidswerkveld richting het sociale veiligheidswerkveld. Vanuit fysiek perspectief is er sprake van een brand die de brandweer onder controle moet krijgen. De directe omgeving dient spoedig afgezet te worden. Vanuit sociaal perspectief gaat het om een brand in een gebedsruimte waar over een paar uur het Suikerfeest zou worden gevierd. Binnen een paar uur worden er veel mensen bij de moskee verwacht die dus moeten worden 
opgevangen. Bovendien zorgt met name de tijdgeest waarin het incident zich afspeelt ervoor dat deze brand ernstige maatschappelijke consequenties heeft.

Naast het onderscheid tussen de twee werkvelden van fysieke en sociale veiligheid zien we dat ook binnen één werkveld het bundelen van krachten en afstemming niet altijd vanzelfsprekend is, waardoor er verzuiling optreedt. Het schietincident in Alphen aan den Rijn is hier een goed voorbeeld van. De dader had al jaren psychische problemen en suïcidale neigingen, en hij was al eerder betrokken bij schietincidenten. Desondanks had hij een wapenvergunning en was hij in het bezit van wapens, iets waar hij met zijn psychiatrische verleden geen toestemming voor had mogen krijgen (IOOV 2011). De vraag rijst dan al snel hoe het kan dat de gegevens van verschillende instanties niet eerder bij elkaar zijn gekomen en niemand (eerder) heeft gesignaleerd dat er sprake was van een risico op een dergelijke escalatie. Elke betrokken partij vormde een stukje van de puzzel, maar de stukjes werden niet bij elkaar gebracht, waardoor er geen compleet overzicht werd gecreëerd. Omdat men binnen het eigen referentiekader bleef en daarmee het 'eigen plaatje' compleet leek, was er ook geen noodzaak een ander referentiekader op te zoeken.

De analyse van de incidenten laat zien dat het in alle gevallen van belang is dat betrokken partijen een brede blik hanteren. De incidenten worden vaak in eerste instantie bestreden door de primaire hulpverleningsdiensten (brandweer, GHOR en politie) als 'fysieke veiligheidsincidenten'. Desalniettemin wordt op basis van de analyse van deze rapporten duidelijk dat alle incidenten zowel fysieke als sociale componenten kennen. Het is daarom van belang dat betrokken partijen een breder perspectief hebben bij de interpretatie, bestrijding en behandeling van (dreigende) incidenten en onveilige situaties, waarbij de invullingen van zowel het fysieke als het sociale perspectief worden meegenomen. Ook het meenemen van de maatschappelijke context (tijdgeest) van een incident of gebeurtenis is onderdeel van dit bredere perspectief en kan helpen om de situaties al in een vroegtijdig stadium goed in te schatten.

\section{Samenwerking, informatiedeling en coördinatie als sleutel voor succes?}

Zoals uit de analyse van de incidenten naar voren komt, is de scheiding tussen fysieke en sociale veiligheid in de praktijk niet volledig houdbaar. Desalniettemin bestaat er ook een scheiding van verantwoordelijkheden en taken tussen de verschillende partijen die werkzaam zijn binnen het veiligheidsdomein. Dit kan blinde vlekken veroorzaken, waardoor niet alle relevante informatie tijdig wordt gedeeld of dat de bredere context van een gebeurtenis onvoldoende in beschouwing wordt genomen. Uit onderzoek van onder andere David Allen (bijv. Allen et al. 2013; Mishra et al. 2011) komt naar voren dat verschillende partijen er verschillende normen en routines op na houden, waardoor een gedeeld begrip van de situatie en hoe deze moet worden aangepakt ontbreekt. Het onderzoek van Allen et al. (2013) richt zich specifiek op de responsfase van ernstige incidenten in de fysieke veiligheid. Wij beargumenteren dat dit probleem niet uitsluitend van toepassing is op fysieke incidenten, maar ook op sociale onveiligheids- 
situaties. Sterker nog, het onderscheid tussen fysieke incidenten en sociale onveiligheidssituaties draagt bij aan de problematiek, omdat partijen door deze scheiding blinde vlekken krijgen als het gaat om de interpretatie van situaties.

Uit onze analyse van incidenten blijkt dat 'fysieke' incidenten over het algemeen ook duidelijk sociale implicaties hebben en sociale veiligheidsproblemen zich ook op fysieke manieren kunnen manifesteren. Het veiligheidsdomein zou in dat opzicht wellicht beter gezien kunnen worden als één geheel, waarbinnen incidenten en gebeurtenissen op integrale wijze worden aangepakt. De complexiteit van veiligheidsproblemen in de samenleving vraagt om multidisciplinaire aanpakken (Stol 2011). In de praktijk is het echter niet realistisch om een volledige integratie van de beide werkvelden te bewerkstelligen, niet in de laatste plaats omdat er in de werkwijze en organisatiestructuur van de beide werkvelden fundamentele verschillen bestaan met betrekking tot de structuur, cultuur en aanpak. Het fysieke veiligheidswerkveld kenmerkt zich door een strakke structuur met vastgestelde verantwoordelijkheden. Leiding en coördinatie, opschaling en informatiemanagement zijn belangrijke processen waar in de afgelopen jaren vanuit de Veiligheidsregio's veel aandacht aan is besteed. Veel van onze respondenten geven aan dat hier een groot verschil ligt met het sociale veiligheidswerkveld. Dit werkveld kent geen vastomlijnde coördinatiestructuur en kenmerkt zich door een veelheid aan partijen die in wisselende samenstellingen betrokken zijn bij situaties.

Uit de interviews en workshops met onze respondenten komt naar voren dat met name de cultuurverschillen en disciplinaire grenzen tussen partijen ervoor zorgen dat samenwerking en informatiedeling vaak moeizaam verlopen. De (vroegtijdige) interpretatie van signalen wordt belemmerd, doordat partijen niet goed kunnen inschatten welke beschikbare informatie voor welke partij relevant is. Andersom ontbreekt het beeld welke informatie bij andere partijen voorhanden is die mogelijk kan bijdragen aan de taken en verantwoordelijkheden van een partij. Ook zorgen cultuurverschillen en de organisatorische verhoudingen tussen partijen voor wantrouwen en negatieve beeldvorming over de legitimiteit van het handelen van andere partijen.

Door de toenemende aandacht die er binnen het veiligheidsdomein is besteed aan multidisciplinaire samenwerking tussen verschillende organisaties, heerst er bij de meeste partijen wel degelijk het besef dat multidisciplinaire samenwerking en een 'bredere blik' nodig zijn om adequater op te treden en op te schalen. Het blijkt in de praktijk vaak lastig voor professionals op het operationele niveau om een bredere blik te hanteren en verbindingen te zoeken met andere partijen. Het is niet voldoende om samenwerking formeel te organiseren, de betrokken actoren moeten ook zelf inzien dat een multidisciplinaire aanpak een toegevoegde waarde heeft. Het moet, zo stelt een van onze respondenten, vanuit een operationele behoefte ontstaan. Voor alle partners in het veiligheidsdomein geldt dat zij primair vanuit hun eigen 'discipline' naar een situatie kijken en daardoor niet altijd in staat zijn om te bedenken of andere partijen ook betrokken zouden moeten worden of wat implicaties zijn die buiten hun specifieke invloedssfeer liggen. Uit gesprekken met onze respondenten komt naar voren dat de wil tot samenwerking er in principe wel is, maar doordat ieder zijn eigen belangen en eigen manier van werken heeft, worden vaak alleen activiteiten opgepakt die binnen de eigen ver- 
antwoordelijkheden vallen, zelfs wanneer er signalen zijn die wellicht voor een andere partij van belang zijn.

Daarnaast zorgt de afstand tussen verschillende organisaties voor misverstanden en wantrouwen tussen partijen. Respondenten vanuit de politie geven aan dat zij het gevoel hebben dat de gemeente niet altijd goed luistert naar de adviezen die zij geven en dat zij wel signalen doorgeven, maar dat ze vaak niet horen wat er met die informatie is gedaan. De gemeente op haar beurt heeft soms moeite om de regierol te pakken, omdat, zo geven enkele gemeenteambtenaren aan, dit door andere partijen niet altijd wordt geaccepteerd.

Los van de vraag of de partijen informatie met andere partijen willen delen, is het soms niet mogelijk om informatie te delen, omdat men zich er vaak niet van bewust is dat de informatie ook relevant kan zijn voor een andere partij. De oorzaken van dit probleem hebben waarschijnlijk deels te maken met het feit dat de ontwikkelingen op het gebied van multidisciplinaire samenwerking vooral gericht zijn op het optreden tijdens (en na) crisissituaties en minder op samenwerking en informatiedeling in normale situaties of in de voorfase van een dreigende situatie (oftewel bij een eerste signaal dat er iets aan de hand is). Uit onze gesprekken met respondenten blijkt echter dat het in de praktijk vaak te laat is om tijdens een geëscaleerde situatie hierbij stil te staan; het zou al in de voorfase duidelijk moeten zijn wie wat doet en daar moet dus inzicht in verkregen worden om hierover onderling afspraken te kunnen maken. Tragische gebeurtenissen zoals het schietincident in Alphen aan den Rijn maken duidelijk hoe relevant het is om signalen vanuit verschillende perspectieven en disciplines vroegtijdig te delen. Zoals veel van onze respondenten vertellen, ligt het probleem met name in het structureel samenwerken en informatie delen. In acute situaties, wanneer de urgentie voor iedereen duidelijk is, kunnen partijen elkaar vaak wel vinden en wordt er samengewerkt, maar wanneer de acute fase weer voorbij is, gaan alle partijen weer terug naar het werk van alledag en komen de disciplinaire perspectieven weer bovendrijven. Met name in niet-opgeschaalde situaties, dreigende situaties of bij situaties die als minder urgent worden gezien, lijken partijen nog onvoldoende in staat om een bredere blik te hanteren als het gaat om de signalering en interpretatie van de situatie.

Daarnaast betekent het opzetten van structurele samenwerkingsverbanden of het maken van afspraken niet automatisch dat mensen de veranderingen ook als zodanig beleven en hun gedrag daarop aanpassen. In de dagelijkse praktijk is het voor betrokkenen moeilijk om het denken vanuit hun eigen perspectief los te laten, waardoor ze zich niet altijd realiseren dat bepaalde informatie voor andere partijen van belang is.

Het heeft echter geen zin om alle informatie met alle partijen te delen, omdat er dan een groot risico is dat de partijen door de bomen het bos niet meer zien. Bovendien is het onwenselijk om specialistische diensten te stimuleren een breed perspectief te hanteren, omdat dit ten koste zou kunnen gaan van de specialistische kennis die juist van essentieel belang is. De oplossing moet dan ook niet gezocht worden in het stimuleren en trainen van samenwerking en informatiedeling, maar in het ondersteunen van een gecoördineerde interpretatie van informatie, zodat deze vervolgens bij de juiste partijen terechtkomt. Dit principe 
is ook het uitgangspunt van het netcentrisch werken dat in de laatste jaren is ingevoerd binnen de Nederlandse Veiligheidsregio's. Binnen het netcentrisch werken staat het werken op basis van een actueel, gedeeld beeld centraal, zodat het proces van leiding en coördinatie bij de crisisbeheersing en rampenbestrijding sneller, daadkrachtiger en doelgerichter verloopt. Deze werkwijze wordt gefaciliteerd door het landelijk crisismanagement systeem (LCMS), waarin zowel aandacht is voor een overzicht van alle essentiële (multidisciplinaire) aspecten van een incident, maar ook voor de specialistische informatie en beelden van deelorganisaties die hen helpen bij het uitvoeren van de eigen specifieke rol en verantwoordelijkheid (IFV 2014). Ook binnen het werkveld van de sociale veiligheid zijn er ontwikkelingen die aansluiten bij de noodzaak om disciplinaire grenzen te overbruggen en gecoördineerd op te treden om escalatie van risicovolle situaties te voorkomen. Het ontstaan van de Veiligheidshuizen is hier een treffend voorbeeld van. Het doel van deze netwerksamenwerkingsverbanden, met partners uit de strafrechtketen, zorgketen, gemeentelijke partners en bestuur, is om onder eenduidige regie te komen tot een ketenoverstijgende aanpak van complexe problematiek (Ministerie van Veiligheid en Justitie 2013). De meerwaarde van deze samenwerking zit in een aanpak die afzonderlijke aanpakken versterkt zonder dat de specifieke (wettelijke) verantwoordelijkheden én kennis van afzonderlijke partijen verloren gaan.

Deze ontwikkelingen en de kennis die is opgedaan binnen de werkvelden van de fysieke en sociale veiligheid vormen de bouwstenen voor het bereiken van meer samenhang binnen de veiligheidszorg in de brede zin van het woord. In de laatste paragraaf van dit artikel schetsen we op basis van onze bevindingen enkele contouren van een mogelijke oplossingsrichting.

\section{Op weg naar meer samenhang en regie}

De samenwerkingsverbanden tussen partijen in het veiligheidsdomein tijdens de bestrijding van crises en onveilige situaties kunnen worden gezien als (ad hoc) genetwerkte organisaties waarbinnen vaak spanningen bestaan tussen de werkwijzen, opvattingen en belangen van de verschillende partijen (Allen 2013; Treurniet et al. 2014). Om deze samenwerking te verbeteren is het van belang dat er een passende regiestructuur ontstaat. Deze moet minder gebaseerd zijn op formele of hiërarchische relaties, maar meer op het inspelen op acuut opkomende signalen en daarop aangepaste samenwerking en uitwisseling van informatie. Uitgangspunt hierbij is dat naarmate de samenwerking langer bestaat, de ervaringen bijdragen aan het versoepelen van de samenwerking en samenhang. Om die reden is er in eerste instantie meer directe regie nodig, waarna er in de loop van de tijd een goed functionerend, min of meer zelfregulerend netwerk kan ontstaan (Treurniet et al. 2014).

Omdat de gemeente een belangrijke (regie)rol speelt bij de aanpak van zowel fysieke als sociale onveiligheid, lijkt zij in eerste instantie een belangrijke partij als het gaat om het streven naar coördinatie en daarmee meer samenhang binnen de veiligheidszorg. In de huidige situatie is de gemeentelijke organisatie echter niet 
in staat om dit proces te regisseren. De gemeente - in de persoon van de burgemeester - heeft weliswaar de regie als het gaat om het lokale veiligheidsbeleid, maar binnen het werkveld van de fysieke veiligheid zijn het van oudsher de primaire hulpverleningsdiensten (brandweer, GHOR en politie) die de kennis en kunde hebben om de incidenten te bestrijden. In de praktijk van de sociale veiligheid hebben de politie en welzijnsorganisaties (zoals de GGD) een belangrijk deel van de benodigde kennis en kunde in huis om calamiteiten aan te pakken en de gemeente is dan ook deels afhankelijk van de samenwerking met deze partijen in het uitoefenen van haar regierol op dit vlak. Daar komt nog bij dat de rol van de gemeente in de afgelopen jaren sterk is veranderd en complexer is geworden (Broekhuizen, Van Steden \& Boutellier 2010; Mein 2010; Terpstra \& Mein 2010). Enerzijds verwachten burgers traditioneel gezien van de overheid dat zij zorgdraagt voor de veiligheid van de samenleving (De Graaf 2013; Van Eeten, Noordegraaf-Eelens, Ferket \& Februari 2012). Anderzijds is in de afgelopen decennia de rol van de overheid sterk aan verandering onderhevig geweest. De neoliberaliseringstendens (Osborne \& Gaebler 1992) heeft er mede aan bijgedragen dat de overheid zich op vele terreinen - zo ook veiligheid - terugtrekt en de verhouding tussen overheid, publieke sector, private sector en burgers complexer is geworden (Boin, 't Hart, Stern \& Sundelius 2005; Boutellier 2007; Schuilenburg 2009; Schuilenburg \& Van Swaaningen 2013; Van der Land 2013; Van Dijk 2004). In twee interactieve workshops hebben we samen met een aantal respondenten vanuit verschillende gemeenten nagedacht over de mogelijkheid om te komen tot een hulpmiddel waarmee de gemeente beter in staat wordt gesteld haar regierol te vervullen. Al snel werd duidelijk dat hierbij de nadruk zou moeten liggen op het stimuleren en faciliteren van een breder perspectief, waarbij er aandacht is voor zowel de fysieke als sociale componenten. Hierdoor worden de verantwoordelijke ambtenaren bij het interpreteren van situaties van (dreigende) onveiligheid in staat gesteld om te bepalen wat er nodig is en op basis daarvan de juiste informatie uit te wisselen met de andere partijen binnen het veiligheidsnetwerk (en binnen de eigen organisatie). Op die manier kunnen de gespecialiseerde partijen binnen de veiligheidsketen hun expertise blijven toepassen, zonder dat de cruciale informatie in de verschillende 'kokers' blijft hangen en kan de gemeente haar regierol beter vervullen.

Dit is met name van belang in de signaleringsfase van een gebeurtenis, omdat er dan nog mogelijkheden zijn om in te grijpen en (verdere) escalatie te voorkomen. Informatie speelt hierbij een sleutelrol. Zoals Wolbers en Boersma (2013) stellen, is hier sprake van een zekere paradox: informatiedeling is zowel deel van het probleem als deel van de oplossing. In de huidige situatie wordt informatie tussen verschillende partijen in het veiligheidsdomein niet altijd gedeeld met relevante partners. Privacy is een belangrijk onderwerp hierbij, maar ook het niet kunnen inschatten welke informatie relevant is voor welke partijen of te veel vanuit één discipline naar een situatie kijken zorgt ervoor dat veel informatie in de verschillende kokers 'blijft hangen'. Het is dan ook van belang dat er op een structurele basis informatie wordt gedeeld (dus niet alleen in crisissituaties). Hierbij is het niet wenselijk om partijen te vragen alle mogelijke informatie onderling beschikbaar te stellen, maar er moet een werkwijze worden ontwikkeld waarbij de regie- 
houder weet welk type informatie relevant is, welke partij(en) deze informatie kunnen leveren, dat er afspraken zijn tussen partijen om de informatiedeling tijdig en soepel te laten verlopen en dat er een systeem is om deze informatie overzichtelijk te maken, zodat de interpretatie gemakkelijk met andere (interne en externe) partijen gedeeld kan worden.

Tijdens de workshops hebben we enkele ruwe schetsen ${ }^{2}$ van een instrument gemaakt, waarbij is uitgegaan van een digitale tool die niet alleen functioneert als een checklist met betrekking tot relevante informatieaspecten (inclusief suggesties over de partner die deze informatie zou kunnen verschaffen), maar die de regievoerder tevens helpt om informatie te ordenen en te koppelen aan eerdere incidenten. Het informatiebeeld dat ontstaat kan waar nodig gedeeld worden met relevante partners. Aansluiting bij een bestaand informatiemanagement systeem (zoals LCMS, dat binnen het werkveld van de fysieke veiligheid gebruikt wordt) kan hierbij nuttig zijn. Ook kan gekeken worden naar de samenwerking binnen constructies als het Veiligheidshuis om het delen van onder andere gevoelige informatie te versoepelen. Ten slotte werd benadrukt dat het van belang is om te beseffen dat een technologische oplossing nooit de volledige oplossing vormt. Het is essentieel om bewustwording bij partijen te verkrijgen over het belang van gecoördineerde informatiedeling en samenwerking binnen het veiligheidsdomein. Door structurele kruisbestuiving en wederzijds vertrouwen op te bouwen kan er een basis geschept worden om eerder en efficiënter informatie uit te wisselen, waardoor de regievoerder in staat wordt gesteld om op het juiste moment zijn signaalfunctie uit te voeren.

\section{Literatuur}

Allen, D.K., S. Karanasios \& A. Norman (2013) Information sharing and interoperability: the case of major incident management. European Journal of Information Systems, 23(4), 418-432.

Boers, J., R. van Steden \& H. Boutellier (2008) Het effect van positieve en negatieve factoren op veiligheidsbeleving. Een kwantitatieve studie onder inwoners van Amsterdam. Tijdschrift voor Veiligheid, 7(3), 34-52.

Boin, A., P. 't Hart, E. Stern \& B. Sundelius (2005) The politics of crisis management. Public leadership under pressure. Cambridge: Cambridge University Press.

Boutellier, H. (2005) Meer dan veilig; over bestuur, bescherming en burgerschap. Den Haag: Boom Juridische uitgevers.

Boutellier, H. (2007) Nodale orde: Veiligheid en burgerschap in een netwerksamenleving (oratie). Amsterdam: Vrije Universiteit, Faculteit der Sociale Wetenschappen.

Brand, R. van den (red.) (2005) Zelfredzaamheid en fysieke veiligheid van burgers. Verkenningen. Arnhem: Nibra.

Broekhuizen, J., R. van Steden \& H. Boutellier (2010) Versnipperde regie. De positie van de gemeente in een lokaal veiligheidsnetwerk. Tijdschrift voor Veiligheid, 9(3).

2 Omdat het hier gaat om zeer ruwe schetsen die zijn opgesteld binnen een vertrouwelijke onderzoekssetting, is het op dit moment niet mogelijk hier meer inzicht in te geven. Indien lezers geïnteresseerd zijn in de bevindingen, kunnen ze contact opnemen met de auteurs van dit artikel. 
Bruinsma, G., W. Bernasco, H. Elffers, W. Huisman, P. van der Laan, J. van der Leun, F. Luijkx, C. de Poot, G. Vanderveen, H. Wagenaar \& F. Weerman (2004) De stad en de sociale onveiligheid. Een 'State of the Art' van wetenschappelijke kennis in Nederland. In: E.R. Muller (red.), Veiligheid. Studies over inhoud, organisatie en maatregelen. Alphen aan den Rijn: Kluwer, 279-318.

Deklerck, J. (2006) Onveiligheid integraal aanpakken: De 'preventiepiramide'. Tijdschrift voor Veiligheid, 5(3), 19-37.

Dijk, A.J. van (2004) Veiligheidsconstructie. In: E.R. Muller (red.), Veiligheid. Studies over inhoud, organisatie en maatregelen. Alphen aan den Rijn: Kluwer, 397-453.

Eeten, M. van, L. Noordegraaf-Eelens, J. Ferket \& M. Februari (2012) Waarom burgers risico's accepteren en waarom bestuurders dat niet zien. Den Haag: Ministerie van Binnenlandse Zaken en Koninkrijksrelaties.

Graaf, B. de (2013) Het temmen van de toekomst. Van een veiligheids- naar een risicocultuur. Tijdschrift over Cultuur \& Criminaliteit, 3(2), 155-172.

Haasjes, J.S. e.a. (2012) De dijk staat op springen. Hoog water in de Veiligheidsregio Groningen. De evaluatie en de bevindingen. Groningen: Veiligheidsregio Groningen.

Helsloot, I. (2007) Voorbij de symboliek. Over de noodzaak van een rationeel perspectief op fysiek veiligheidsbeleid. Den Haag: Boom Juridische uitgevers.

Helsloot, I., W. Jong, M. Zannoni, L.A. Vinck Mcdm, J.M.G. Lukkes \& E.R. Muller (2004) Ongeval met ingestorte steiger Amercentrale 28 september 2003. Evaluatie van de rampenbestrijding. Den Haag: COT Instituut voor Veiligheids- en Crisismanagement B.V.

IFV (2014) Referentiekader Netcentrische Crisisbeheersing. Herziene versie, verwachte publicatie in 2014. Arnhem: Instituut Fysieke Veiligheid.

IOOV (2011) Schietincident in 'De Ridderhof Alphen aan den Rijn. Den Haag: Inspectie Openbare Orde en Veiligheid (Ministerie van Veiligheid en Justitie).

Land, M. van der (2013) Burgers voor/tegen burgers: Buurtwachten in Nederland en hun verbindingen met bewoners, politie en gemeente. Tijdschrift voor Veiligheid, 12(2), 62-78.

Meerenburgh, J.P., L.M.A. Mentink, L.M. Hanstede \& J.M. Perrier (2012) Paasvuur Espelo. Enschede: Veiligheidsregio Twente.

Mein, A. (2010) Uitbreiding bevoegdheden ter handhaving van de openbare orde en veiligheid. Een versterking of verzwakking van de positie van de burgemeester?. Tijdschrift voor Veiligheid, 9(3), 34-44.

Mischra, J.L., D.K. Allen \& A.D. Pearman (2011) Information Sharing during Multi-Agency Major Incidents. Proceedings of the 74th ASIS\&T Annual Meeting, Vol. 48.

Noije, L. van (2011) Tien jaar Tijdschrift voor Veiligheid. Tijdschrift voor Veiligheid, 10(4), 3-9.

Osborne, D. \& T. Gaebler (1992) Reinventing government. How the entrepreneurial spirit is transforming the public sector. Reading, MA: Addison-Wesley.

Pleysier, S. (2008) 'Integrale veiligheid' als dogma? Grenzen aan het heersende veiligheidsdiscours. Tijdschrift voor Veiligheid, 7(1), 34-46.

Regionale Brandweer Zuid-Holland Zuid (2007) Feitenevaluatie incident buisleidingenstraat Heinenoord 12 oktober 2007. Gemeente Binnenmaas.

Resodihardjo, S. \& A. Kors-Walraven (2012) Veiligheid: Een almaar uitdijend concept. Tijdschrift voor Veiligheid, 11(1), 3-16.

Scholtens, A. \& I. Helsloot (red.) (2008) Stroomuitval in de Bommeler- en Tielerwaard in December 2007. Nederlands Instituut Fysieke Veiligheid.

Schuilenburg, M. (2009) De securisering van de samenleving. Over de relatie tussen veiligheidszorg, bestuur en quasistrafrecht. Krisis, 3, 6-22. 
Schuilenburg, M. \& R. van Swaaningen (2013) Veiligheid in een laatmoderne cultuur. Tijdschrift over Cultuur \& Criminaliteit, 3(2), 109-122.

Stol, W. (2011) Tien jaar veiligheidsonderzoek in het Tijdschrift voor Veiligheid. Weerspiegeling van een vakgebied in ontwikkeling. Tijdschrift voor Veiligheid, 10(4), 10-24.

Terpstra, J. \& A. Mein (2010) De positie van de gemeente in de veiligheidszorg. Een inleiding. Tijdschrift voor Veiligheid, 9(3), 3-8.

Treurniet, W., R. Logtenberg \& P. Groenewegen (2014) Governance of occasional multisector networks. In: S.R. Hiltz, M.S. Pfaff, L. Plotnick \& P.C. Shih (red.), Proceedings of het 11th International ISCRAM Conference. University Park, Pennsylvania, 120-124.

Witte, R., P. Brassé \& K. Schra (2005) Moskeebrand in Helden. Evaluatie van de aanpak en lessen voor de toekomst. Utrecht: FORUM Instituut voor Multiculturele Ontwikkeling.

Wolbers, J. \& K. Boersma (2013) The Common Operational Picture as Collective Sensemaking. Journal of Contingencies and Crisis Management, 21(4), 186-199. 